\title{
Manyetik Düșey Gradyometre Yönteminde Farklı Alıcı Aralıklarının Seçimi
}

\author{
The Selection of Different Sensor Intervals in Vertical Magnetic \\ Gradiometer Method
}

\author{
MUZAFFER ÖZGÜ ARISOY', CEMAL KAYA² \\ ${ }^{1}$ Maden Tetkik ve Arama Genel Müdürlüğü, Jeofizik Etütleri Dairesi Başkanlığı, 06800 Çankaya, \\ ANKARA \\ ${ }^{2}$ Kayen Enerji Koza Sokak 37/6, GOP Çankaya, Ankara
}

Geliș (received) : 09 Ocak (january) 2014

Kabul (accepted) : 18 Temmuz (July) 2014

\section{Öz}

Bu çalıșmada, yakın yüzey araștırmalarında yaygın olarak kullanılan düșey gradyometre yönteminde farklı manyetometre aralıkları seçiminin düșey manyetik gradyent verileri üzerindeki etkileri incelenmiștir. Karada yapılan arazi çalıșmalarında kullanılan düșey gradyometrelerin birçoğu $0.5,1$ ve $1.5 \mathrm{~m}$ alıcı aralıklarının seçimine izin vermektedir. Bu nedenle çalıșma kapsamında, hem model hem de arazi çalıșmaları için alııı aralıkları $0.5,1$ ve $1.5 \mathrm{~m}$ olarak seçilmiș ve karșılaștırmalar bu alıcı aralıkları kullanılarak yapıımıștır. Model çalıșması için kullanıșlı bir yakın yüzey modelinden hesaplanan kuramsal ve arazi çalıșması için arkeolojik bir alanda toplanan düșey manyetik gradyent verileri kullanılmıștır. Günümüzde düșey gradyent ölçümlerinde geleneksel olarak $0.5 \mathrm{~m}$ alııı aralığı kullanılmaktadır. Model ve arazi çalıșmalarından görüleceği üzere, belirtiye neden olan kaynakların fiziksel ve geometrik özelliklerinin önceden kestirilmesi durumunda ve gürültü etkileri göz önünde bulundurulduğunda farklı alıcı aralıkları seçiminin önemi ortaya çıkmaktadır.

Key Words: Alıcı aralığı, düșey gradyent, manyetik yöntem

\begin{abstract}
In this study, the effects of selection of the different magnetometer separations in vertical gradiometer method that widely used in near surface studies on the vertical magnetic gradient data are investigated. Many vertical gradiometers that used in ground studies allow the selection of 0.5, 1 and $1.5 \mathrm{~m}$ receiver separations. For this reason in the frame of the study, both in the modelling and field studies, the receiver separations are selected as $0.5,1$ and $1.5 \mathrm{~m}$ and comparisons are done using these receiver separations. For the model study a theoretical dataset computed from a functional subsurface model and for the field study a real archaeological vertical magnetic gradient dataset were used. Traditionally, $0.5 \mathrm{~m}$ receiver separation is used in the vertical gradient surveys in nowadays. As can be seen both in the modelling and field studies, the necessity and importance of the selection of different receiver separations are appeared in cases of the estimation of physical and geometric parameters of the magnetic sources that caused the anomaly and in cases of the consideration of the noise effects.
\end{abstract}

Anahtar Kelimeler: Receiver separation, vertical gradient, magnetic method

M. ARISOY
e-posta: muzafferozgu.arisoy@mta.gov.tr 


\section{GiRiș}

Arama jeofiziğinin en eski yöntemlerinden biri olan manyetik yöntemin amacı yer manyetik alanındaki değișimlerin ölçülmesidir. Yer manyetik alanı, doğal (iyonosfer veya manyetosferdeki elektrik akımları) ve yapay (endüstriyel aktiviteler vb.) kaynaklara bağlı olarak zamana göre hızlı değișimler gösterir. Bu tür değișimleri veriden ayıklamanın iki yolu bulunmaktadır. Bunlardan ilkinde iki manyetometre kullanılır. Burada, birinci manyetometreyle her ölçü noktasında ölçü alınırken diğer manyetometreyle önceden belirlenen bir noktada (baz noktası) belirli zaman aralıklarında ölçüler alınır. İkinci ve en kullanıșlı yol ise; aynı sistem içinde birbirine yakın uzaklıkta konumlandırılan iki manyetometre ile eș-zamanlı ölçüler almaktır (Tabbagh vd., 1997).

Yer manyetik alanının yatay ve düșey yöndeki türevlerinin ölçülmesi ve kuramsal olarak hesaplanması manyetik verilerin yorumunda önemli bir yer tutmaktadır. Yer manyetik alanının yatay ve düșey yöndeki türevleri kuramsal modeller üzerinde birçok araștırmacı tarafından incelenmiștir (Henderson ve Zietz, 1949; Affleck, 1958; Barongo, 1985). Yer manyetik alanının yatay türevleri aranan yapının ölçü alanı üzerindeki dağılımının araștırılmasında, düșey türevleri ise derin yapılara ait etkilerin veriden ayıklanıp yüzeye yakın yapıların etkilerinin ön plana çıkartılmasında kullanılmaktadır.

Jeofizik literatüründe manyetik gradyometrenin tanımı ilk kez Haalck (1925; Hood ve McClure, 1965) tarafından verilmiștir. Haalck (1925), manyetik gradyent ölçümlerini hızlı ve verimli bir biçimde gerçekleștiren iki bobinli bir manyetik indükleyici önermiștir. Ancak bu fikri teoride kalıp uygulamaya koyamamıștır. Roman ve Sermon (1934; Hood ve McClure, 1965) iki bobinli manyetik indükleyici geliștirip bazı test ölçümleri sonucunda yatay manyetik gradyent değerlerini ölçmeyi bașarmıșlardır. Rikitake ve Tanaoka (1960) proton manyetometreleri ile Japonya' daki Mihara dağında volkanik aktiviteden kaynaklanan yer manyetik alanındaki değișimleri gözlemek için bir manyetometreyi volkan üzerinde, diğerini de bir baz istasyonunda tutarak eș-zamanlı ölçümler almıșlardır. Aitken (1961), gradyometre ölçümlerini aynı düzenek üzerinde almayı önermiștir. Bir düzenek üzerine yerleștirdiği iki proton manyetometresi ile eș-zamanlı ölçüler toplamıștır. Bu çalıșma, gradyometre yöntemiyle arkeolojik kalıntıların araștırımasına ilk örnektir. Daha sonraki yıllarda yöntemin arazi uygulamaları ve kuramsal modeller üzerinde denenmesi birçok araștırmacı tarafından yapılmıștır (Barongo, 1985; Keating ve Pilkington, 1990; Breiner, 1999).

Teknolojideki gelișmelerle birlikte günümüzde gradyometre ölçümleri oldukça hızlı ve duyarlı bir biçimde yapılmaktadır. Bu nedenden dolayı yöntem, arkeolojik amaçlı araștırmalarda, gömülü metal nesnelerin araștırılmasında ve diğer yakın yüzey araștırmalarında en sık kullanılan jeofizik yöntem haline gelmiștir.

\section{DÜȘEY GRADYENT ÖLÇÜM TEKNIĞi}

Düșey gradyometre yönteminin esası birbirinden farklı yükseklikte bulunan iki alıcı ile her ölçüm noktasında yer manyetik alanın toplam bileșenini ölçmeye dayanmaktadır. Her ölçü noktasındaki düșey gradyent verisi, farklı alıcı uzaklıklarında ölçülen yer manyetik alanın toplam bileșenleri farkının alıcılar arasındaki uzaklığa bölünmesiyle elde edilir (Breiner, 1999). Bu ișlem basitçe,

$\frac{\partial T}{\partial h}=\frac{T_{a l t}-T_{u s t}}{\Delta h}$

olarak verilir. Burada; $T_{\text {alt }}$ alt alıcı ile ölçülen toplam manyetik alan değerini, $T_{\text {üst }}$ üst alıcı ile ölçülen toplam manyetik alan değerini, $\Delta h$ ise alıcılar arasındaki uzaklığı göstermektedir. Arazi çalıșmalarında ölçümler kaynak uzanımına dik hatlar boyunca ve genellikle sürekli kayıtlar alınarak gerçekleștirilmektedir (Șekil 1). Daha sonra ölçü değerleri sayısallaștırılarak ölçü noktalarına dağıtııır.

Arazi verilerinin hızlı toplanması dıșında da yöntemin üstün yönleri bulunmaktadır. Bunlardan ilki; yöntemde iki alıcı ile eș-zamanlı ölçüler alındığından günlük değișim düzeltmesi yapılmasına gerek yoktur. Alt alıcının hem derin hem de yüzeye yakın yapılardan etkilendiği ve üst alıcının da derin yapılardan etkilendiği göz önüne alındığında, bu iki alıcı ile ölçülen verilerin farklarının yüzeye yakın yapıların etkilerini 


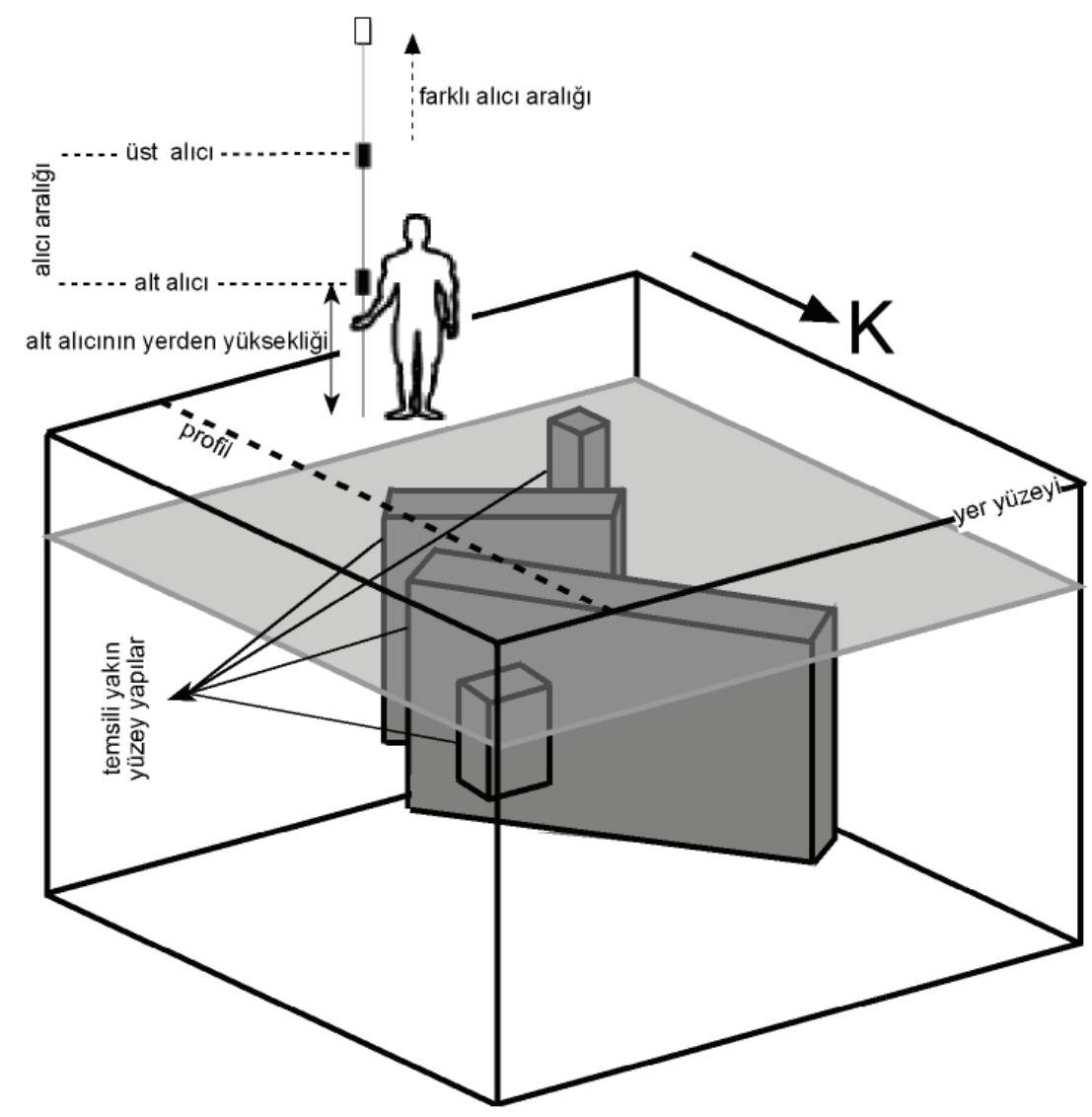

Șekil 1. Düșey manyetik gradyometre yönteminde alıcı geometrileri ve arazide ölçü alımı. Figure 1. Receiver geometries and field measurement in the vertical gradiometer method.

göstereceği açıktır. Bu nedenle düșey manyetik gradyent verilerinde bölgesel-yerel (rejyonal-rezidüel) ayrımın yapılmasına gerek yoktur. Yöntemin diğer bir önemli üstün yanı düșey manyetik gradyent ölçülerinin yanı sıra, iki farkı yükseklikte ölçülen toplam manyetik alan verilerinin de bulunmasıyla, gözlemsel ve sayısal yorumlamaya yardımcı olabilecek veri setlerinin elde edilmiș olmasıdır.

\section{DÜȘEY GRADYOMETRE YÖNTEMINDE FARKLI ALICI ARALIKLARI}

Bir gradyometrenin duyarılığı alıcılar arasındaki uzaklığa bağlıdır. Yöntemde farklı alıcı aralıkları seçiminin önemi, kuramsal ve arazi verileri kullanılarak birtakım araștırıcılar tarafından tartıșılmıștır (Bartington ve Chapman, 2004; Arısoy ve Ulugergerli, 2005; Arısoy, 2007). Karada yapılan arazi çalıșmalarında kullanılan düșey gradyometrelerin birçoğu $0.5,1$ ve $1.5 \mathrm{~m}$ alıcı aralıklarının seçimine izin vermektedir. Bununla birlikte $0.5 \mathrm{~m}$ alıcı aralığının kullanımı diğer seçeneklere göre kullanım kolaylığı sağlaması açısından daha yaygındır.

Yer manyetik alanının $z_{o}$ yüksekliğinde ölçülen $T$ toplam bileșeninin Fourier Dönüșümü așağıdaki eșitlikte verilmiștir.

$T\left(k_{x}, k_{y}, z_{0}\right)=\int^{\infty} \int^{\infty} T\left(x, y, z_{0}\right) e^{-2 \pi i\left(k_{x}+k_{y}\right)} d x d y(2)$ Burada $k_{x}$ ve $k_{y}$-sirasıyla $x$ ve $y$ yönündeki dalga sayılarıdır. Bu bağıntı herhangi bir uzanım seviyesi $(z)$ için

$T\left(k_{x}, k_{y}, z\right)=T\left(k_{x}, k_{y}, z_{0}\right) e^{-\left(z_{0}-z\right) 2 \pi \sqrt{k_{x}^{2}+k_{y}{ }^{2}}}$

eșitliğine dönüșür. Toplam manyetik alanın $z_{\text {。 }}$ yüksekliğindeki birinci düșey türevi dalga sayısı ortamında

$T_{z}\left(k_{x}, k_{y}, z_{0}\right)=T\left(k_{x}, k_{y}, z_{0}\right) 2 \pi \sqrt{k_{x}^{2}+k_{y}^{2}}$ 
olarak yazılır. $z_{1}$ ve $z_{2}$ yükseklikleri için düșey gradyent süzgeç fonksiyonu dalga sayısı ortamında,

$$
G\left(k_{x}, k_{y}, z_{0}\right)=\frac{2 \pi \sqrt{k_{x}^{2}+k_{y}^{2}}}{e^{-\left(z_{0}-z_{1}\right) 2 \pi \sqrt{k_{x}^{2}+k_{y}{ }^{2}}}-e^{-\left(z_{0}-z_{2}\right) 2 \pi \sqrt{k_{x}{ }^{2}+k_{y}{ }^{2}}}}
$$

ifadesiyle verilmiștir (Tabbagh vd., 1997). Bu süzgeç fonksiyonu kullanılarak manyetik alan verileri düșey manyetik gradyent verilerine dönüștürülebilir. Eșitlik (5) kullanılarak 0.5, 1 ve $1.5 \mathrm{~m}$ alıcı aralıkları için hesaplanan düșey gradyent süzgeç fonksiyonunun normalize edilmiș genlik spektrumları Șekil 2'de verilmiștir. Șekil 2'de görüldüğü gibi düșey gradyent süzgeci temelde yüksek geçișli bir süzgeçtir. Șekil 2a'da $0.5 \mathrm{~m}$ alıcı aralığı için verilen süzgecin kesme dalga sayısı yüksek bir dalga sayısı değerinde, Șekil $2 b$ 'de $1 \mathrm{~m}$ alıcı aralığı için verilen süzgecin kesme dalga sayısı $0.5 \mathrm{~m}$ alıcı aralığına göre daha düșük bir dalga sayısı değerinde, Șekil $2 c$ 'de $1.5 \mathrm{~m}$ alıcı aralığı için verilen süzgecin kesme dalga sayısı da diğer alıcı aralıklarına göre daha düșük bir dalga sayısı değerindedir. Sonuç olarak, alıcı aralıkları arttırıldığında düșey gradyent süzgecinin kesme dalga sayısı küçülmektedir. Böylece veride yüksek dalga sayısı içeren bileșenler bastırımakta; diğer bir deyișle kısa dalga boyları süzgeçlenerek, verinin gürültü içeriği düșürülmektedir. Bu özellik veri ișlemede ve yorumlamada yorumcuya önemli bir kolaylık sağlayacaktır.

Șekil 3'de farklı alıcı aralıklarının profil verilerinde gürültü etkisini gösterebilmek için olușturulan model ve $0.5,1$ ve $1.5 \mathrm{~m}$ alıcı aralıkları için hesaplanan düșey manyetik gradyent profil eğrileri verilmiștir. Tüm hesaplamalarda veriye, verinin en yüksek genlik değerinin \%5' i kadar rastsal gürültü eklenmiștir. Hesaplamalarda alt alıcının yerden yüksekliği $0.5 \mathrm{~m}$ olarak seçilmiștir. Modeldeki tüm yapıların mıknatıslanma șiddetleri $1 \mathrm{~A} / \mathrm{m}$, yer manyetik alanının eğim ve sapma açıları da sırasıyla $90^{\circ}$ ve $0^{\circ}$ olarak seçilmiștir. Prizmatik yapıların yatay ve düșey yönde boyutları Șekil 3d'de görülmektedir. Șekil 3d'deki model kullanılarak $0.5 \mathrm{~m}$ alıcı aralığı için hesaplanan düșey manyetik gradyent profil eğrisi Șekil 3a'da, benzer șekilde 1 ve $1.5 \mathrm{~m}$ alıcı aralığı için hesaplanan profil eğrileri de sırasıyla
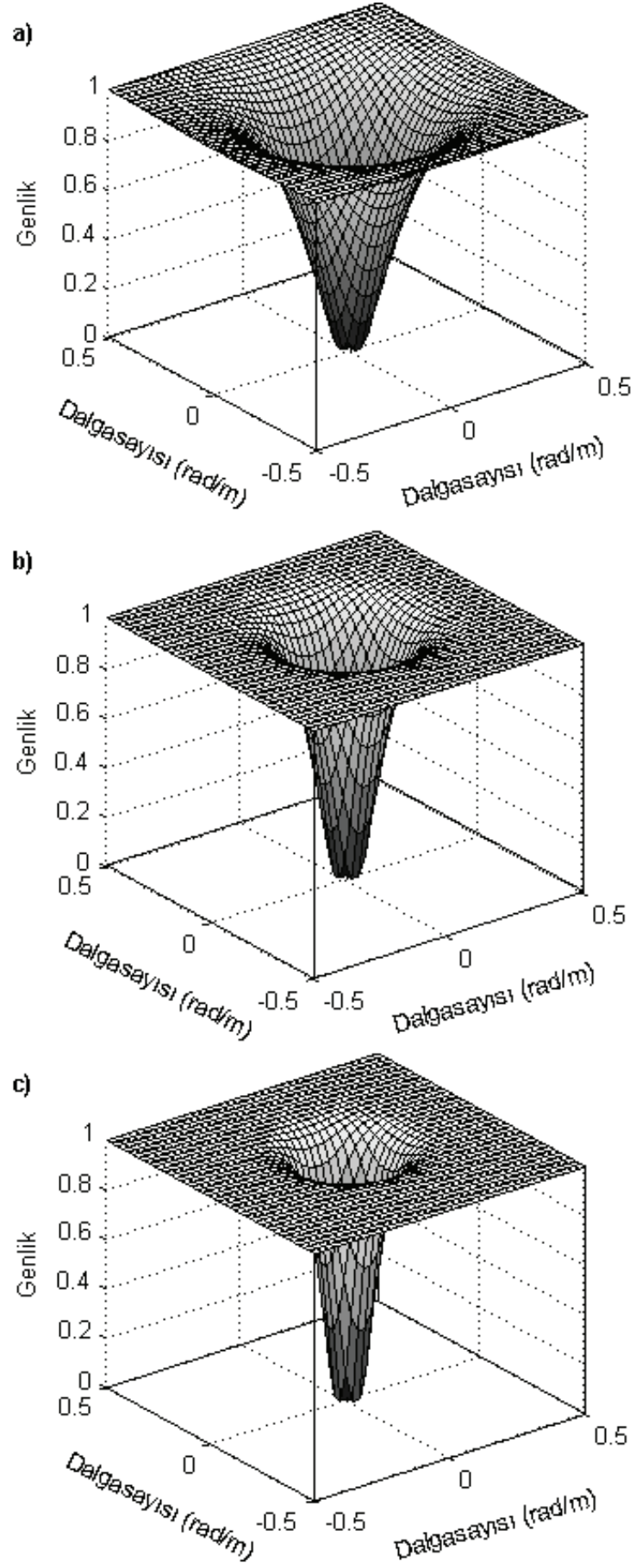

Șekil 2. Farklı alıcı aralıkları için düșey gradyent süzgeç fonksiyonunun normalize edilmiș genlik spektrumları (a) $0.5 \mathrm{~m}$ alıcı aralığı, (b) $1 \mathrm{~m}$ alıcı aralığı, (c) $1.5 \mathrm{~m}$ alıcı aralığı.

Figure 2. Normalized amplitude spectrum of the vertical gradient filter function for different receiver separations (a) $0.5 \mathrm{~m}$ receiver separation, (b) $1 \mathrm{~m}$ receiver separation, (c) $1.5 \mathrm{~m}$ receiver separation. 
a)

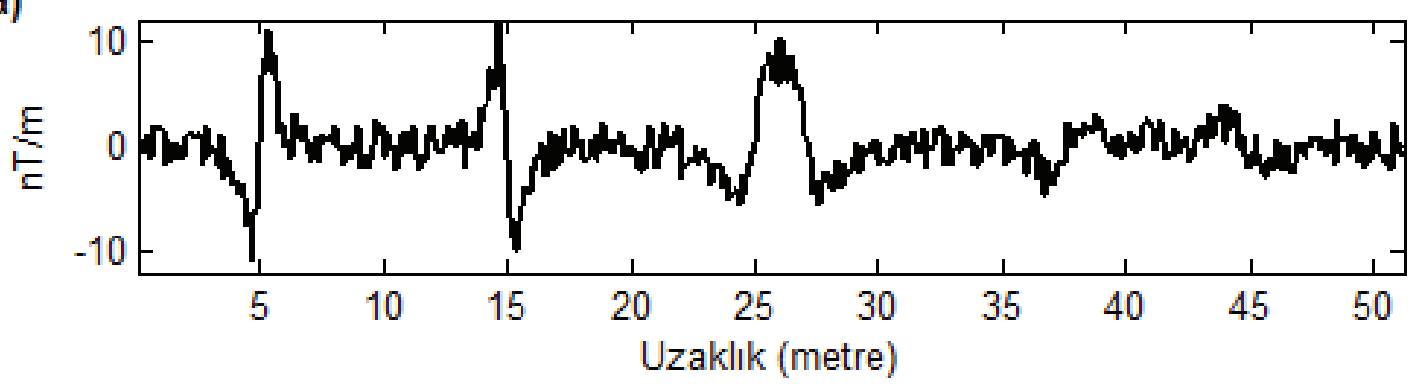

b)

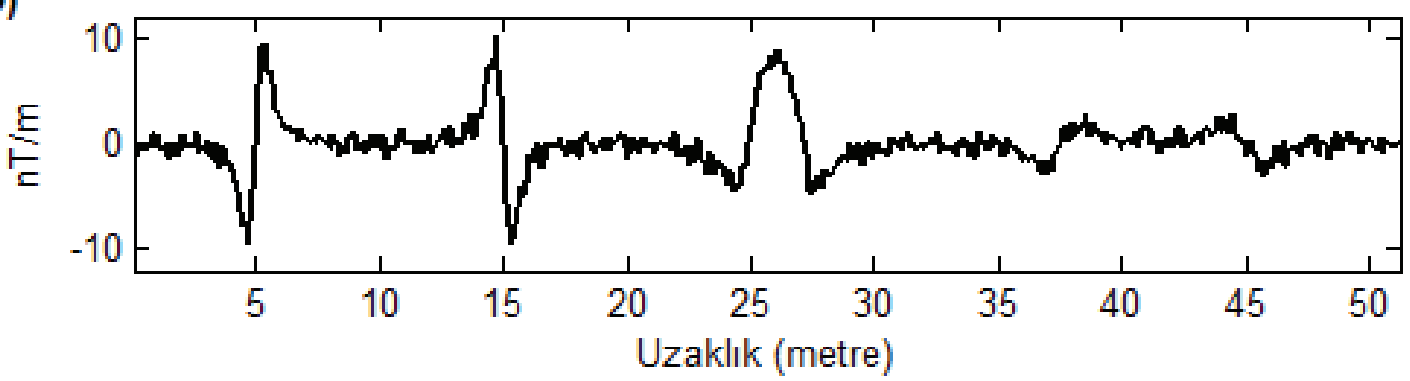

c)

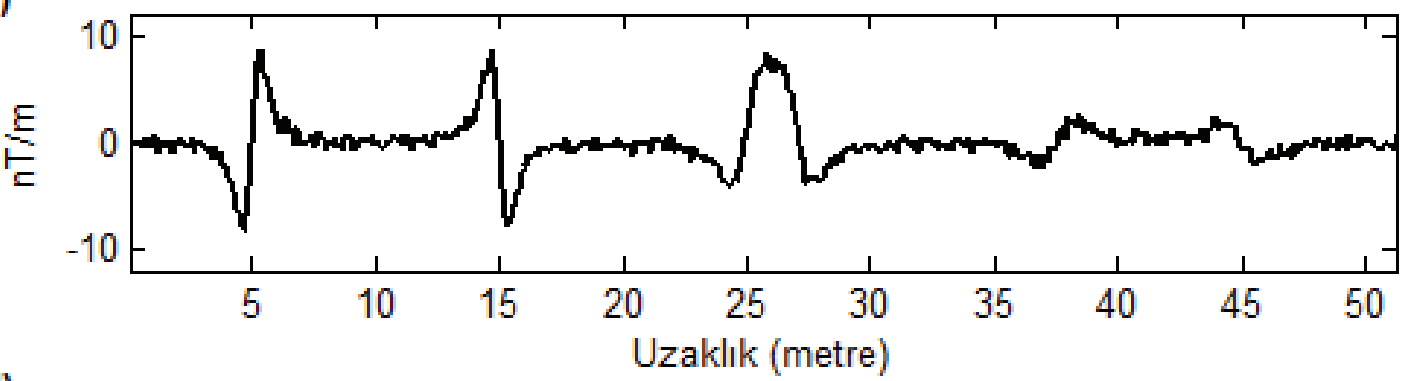

d)

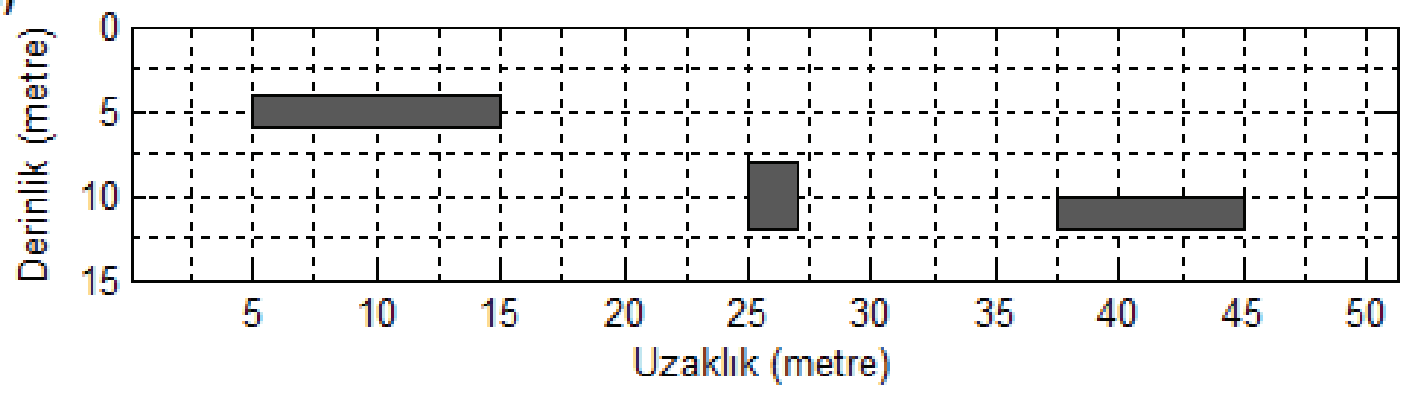

Șekil 3. Üç adet prizmatik yapı kullanılarak olușturulan iki boyutlu yeraltı modeli ve hesaplanan düșey manyetik gradyent profil eğrileri (a) $0.5 \mathrm{~m}$ alıcı aralığı, (b) $1 \mathrm{~m}$ alıcı aralığı, (c) $1.5 \mathrm{~m}$ alıcı aralığı, (d) iki boyutlu yeraltı modeli.

Figure 3.2D subsurface model that created using three prismatic bodies and calculated vertical magnetic gradient profile curves (a) $0.5 \mathrm{~m}$ receiver separation, (b) $1 \mathrm{~m}$ receiver separation, (c) $1.5 \mathrm{~m}$ receiver separation, (d) $2 D$ subsurface model.

Șekil 3b ve Șekil 3c'de verilmiștir. Eğrilerde düșey eksen değerleri incelendiğinde, $0.5 \mathrm{~m}$ alıcı aralığı kullanılarak hesaplanan düșey gradyent verisinin diğer alıcı aralıkları ile hesaplanan verilerden hem sığ hem de derin yapılar için daha duyarlı olduğu ancak verinin gürültü içermesi durumunda bu alıcı aralığının gürültü içeriğini oldukça kuvvetlendirdiği görülmektedir. Özellikle Șekil 3d'de verilen modelin en sağındaki yapıya ait belirti, gürültü varlığının kuvvetlenmesi 
nedeniyle neredeyse gözle takip edilemeyecek duruma gelmiștir. Kademeli olarak alıcı aralığının arttırımasıyla; $1 \mathrm{~m}$ (Șekil 3b) ve $1.5 \mathrm{~m}$ (Șekil 3c) alıcı aralıkları için düșey gradyent eğrilerinde gürültü varlığının bastırıldığı ve özellikle derin yapılara ait belirtilerin daha da belirginleștiği görülmektedir.

\section{DÜȘEY MANYETIK GRADYENT BELIRTILERINDE SINIR GÖRÜNTÜLEME}

Manyetik yöntemlerde belirtiye neden olan yeraltı yapılarının yatay yönde sınırlarının izlenmesi görüntü ișlemede ele alınan en önemli konulardan biridir. Mıknatıslanma özelliği gösteren yeraltı yapılarının yatay yönde sınırlarının görüntülenmesi için kullanılan süzgeçlerin tümü verinin türevlerinin hesaplanmasını gerektirmektedir. Bu süzgeçlerden sıklıkla kullanılanlarından birisi analitik sinyal süzgecidir. Nabighian (1972) tarafından profil verileri için analitik sinyal

$$
|A|=\sqrt{\left(\frac{\partial T}{\partial x}\right)^{2}+\left(\frac{\partial T}{\partial z}\right)^{2}}
$$

olarak verilmiștir. Burada $\partial T / \partial x$ ve $\partial T / \partial z$ sırasıyla toplam manyetik alanın yatay ve düșey türevleridir. Bağıntı (6)'da $T$ yerine verinin birinci mertebe düșey türevi $\left(T_{z}\right)$ yazıldığında,

$$
|A|=\sqrt{\left(\frac{\partial T_{z}}{\partial x}\right)^{2}+\left(\frac{\partial T_{z}}{\partial z}\right)^{2}}
$$

elde edilir. Burada $\partial T_{z} / \partial x$ ve $\partial T_{z} / \partial z$ sırasıyla düșey gradyentin yatay ve düșey türevleridir. Üç boyutlu veriler için

$$
|A|=\sqrt{\left(\frac{\partial T_{z}}{\partial x}\right)^{2}+\left(\frac{\partial T_{z}}{\partial y}\right)^{2}+\left(\frac{\partial T_{z}}{\partial z}\right)^{2}}
$$

eșitliği yazılacaktır (Tabbagh vd., 1997). Analitik sinyal genliği kaynak yapıların üzerinde çan șekilli belirtiler sunar. Önemli özelliklerinden birisi de profil verileri için mıknatıslanma yönüne bağımlı olmamasıdır, aynı özellik harita verileri için geçerli değildir (Li, 2006). Analitik sinyal, türev tabanlı bir yöntem olduğundan, doğası gereği veride gürültü içeriğini arttıran bir yöntemdir.
Șekil 3'de verilen gürültü eklenmiș düșey manyetik gradyent verilerinin analitik sinyal genlikleri $0.5 \mathrm{~m}$ alıcı aralığı için Șekil $4 a^{\prime} d a, 1 \mathrm{~m}$ alıcı aralığı için Şekil 4b'de ve $1.5 \mathrm{~m}$ alıcı aralığı için Șekil 4c'de verilmiștir. $0.5 \mathrm{~m}$ alıcı aralığı için hesaplanan düșey manyetik gradyent verisinin analitik sinyal sonucu (Șekil 4a) incelendiğinde, modelin ortasındaki ve sağındaki her iki derin yapıya (Șekil 4d) ait sınır, gürültünün etkisiyle belirlenememiștir. $1 \mathrm{~m}$ alıcı aralığı için hesaplanan analitik sinyal genliği (Șekil 4b) sonucunda modelin ortasında bulunan yapıya ait sınırlar izlenebilmekte, fakat sağda bulunan yapının kenarlarını belirlemede yöntem bașarısız sonuç üretmiștir. 1.5m alıcı aralığı için hesaplanan analitik sinyal genliği (Șekil 4c) sonucu diğer sonuçlara göre gürültü etkisi düșürüldüğünden dolayı her üç yapının sınırlarının izlenmesinde daha bașarılıdır.

Harita verileri için alıcı aralığı seçiminin veri ve analitik sinyal genlikleri üzerindeki etkisi Șekil 5'de gösterilmiștir. Yeraltı modeli beș adet üç boyutlu prizmatik yapı kullanılarak olușturulmuș ve sırasıyla modelin plan görüntüsü Șekil 5a'da ve üç boyutlu perspektif görüntüsü Șekil $5 b$ 'de gösterilmiștir. Tüm yapıların mıknatıslanma șiddetleri $1 \mathrm{~A} / \mathrm{m}$, yer manyetik alanının eğim ve sapma açıları sırasıyla $90^{\circ}$ ve $0^{\circ}$ ve alt alıcının yerden yüksekliği $0.2 \mathrm{~m}$ olarak seçilmiștir. Tüm hesaplamalarda veriye, verinin en yüksek genlik değerinin \%5' i kadar rastsal gürültü eklenmiștir. Șekil 5a-b'de verilen modelden hesaplanan düșey gradyent görüntü haritaları $0.5 \mathrm{~m}$ alıcı aralığı için Șekil 5c'de, $1 \mathrm{~m}$ alıcı aralığı için Șekil $5 \mathrm{~d}$ 'de ve $1.5 \mathrm{~m}$ alıcı aralığı için Șekil 5 e'de verilmiștir. Modelde verilen tüm yapılara ait belirtiler her alıcı aralığı için hesaplanan düșey gradyent görüntü haritalarında görülebilmektedir. Gürültü etkisi alıcı aralıklarının kademeli olarak arttırımasına paralel bir șekilde azalmıștır (Șekil 5c-d-e). Bunun sonucu olarak modelin ortasında ve derinde bulunan küçük boyutlu yapıya ait belirtinin görülebilirliği, artan alıcı aralığıyla birlikte artmıștır. Șekil 5c-d-e'de farklı alıcı aralıkları için verilen düșey gradyent verilerinin analitik sinyal görüntü haritaları $0.5 \mathrm{~m}$ alıcı aralığı için Șekil $5 f^{\prime}$ de, $1 \mathrm{~m}$ alıcı aralığı için Șekil $5 \mathrm{~g}$ 'de ve $1.5 \mathrm{~m}$ alıcı aralığı için Șekil 5 h'de verilmiștir. $0.5 \mathrm{~m}$ alıcı aralığı için verilen analitik sinyal sonucunda (Șe- 
a)

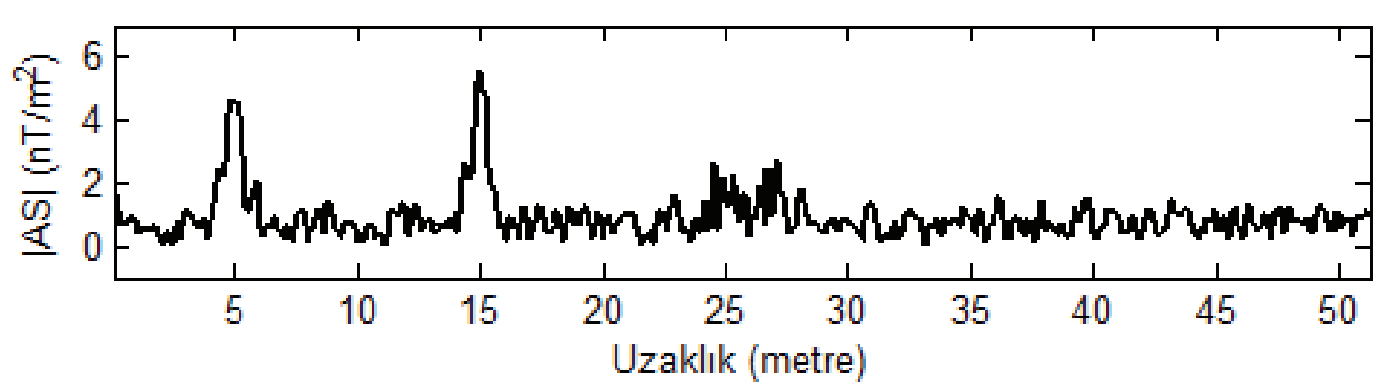

b)

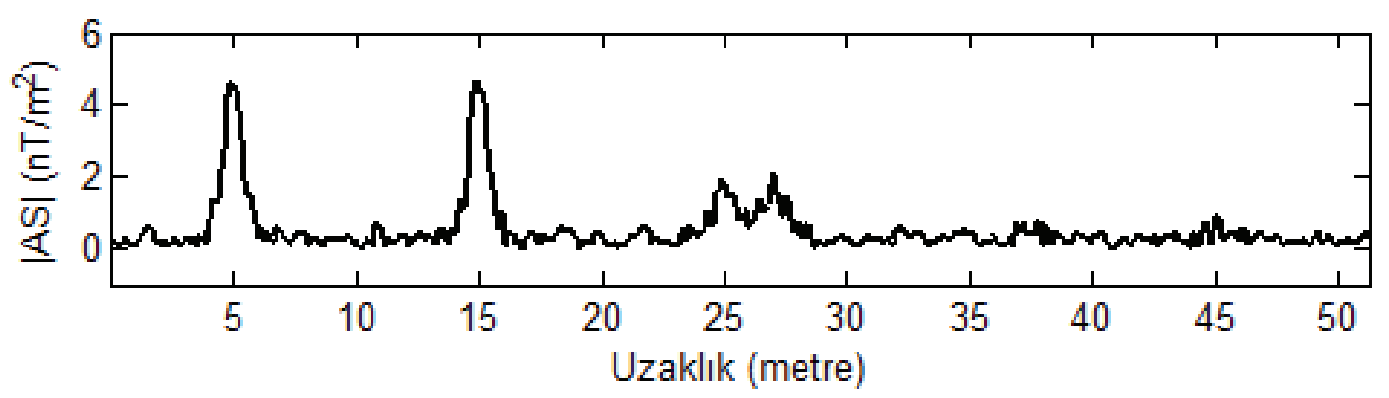

c)

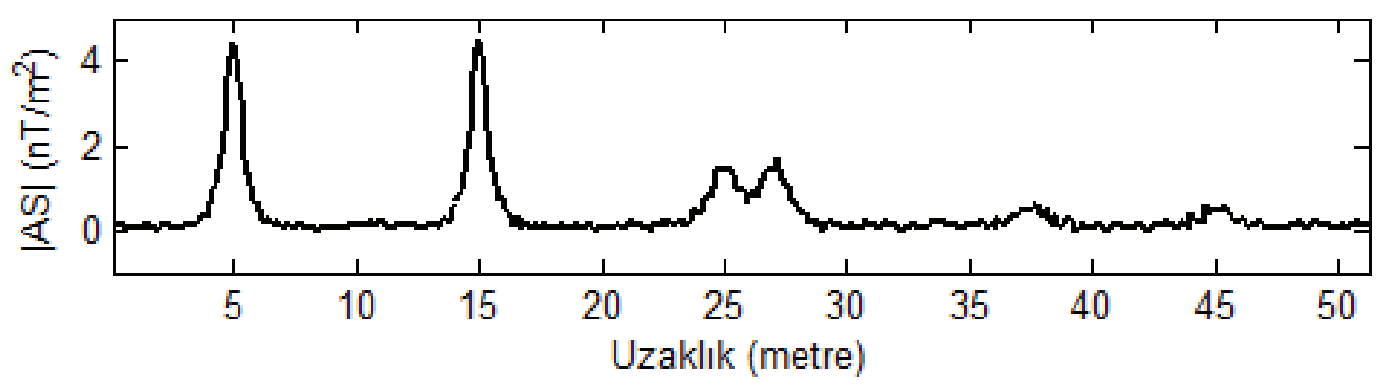

d)

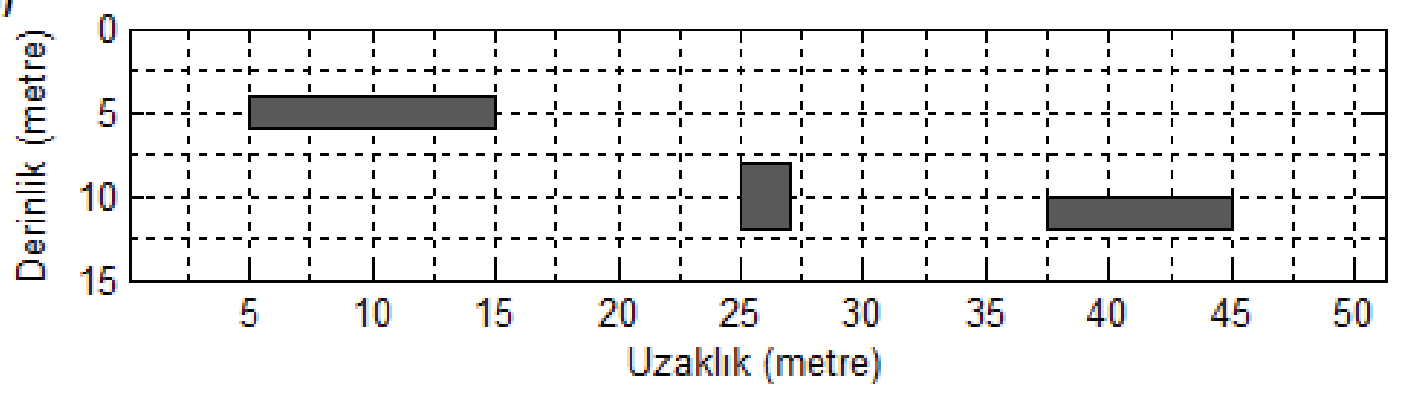

Șekil 4. Șekil 3'de farklı alıcı aralıkları için hesaplanan gürültü eklenmiș düșey manyetik gradyent verilerinin analitik sinyal genlik eğrileri (a) $0.5 \mathrm{~m}$ alıcı aralığı, (b) $1 \mathrm{~m}$ alıcı aralığı, (c) $1.5 \mathrm{~m}$ alıcı aralığı, (d) íki boyutlu yeraltı modeli.

Figure 4. The analytic signal amplitude curves of noise-added vertical magnetic gradient data calculated from different receiver separations that are given in Figure 3 (a) $0.5 \mathrm{~m}$ receiver separation, (b) $1 \mathrm{~m}$ receiver separation, (c) $1.5 \mathrm{~m}$ receiver separation, (d) $2 \mathrm{D}$ subsurface model.

kil 5f), gürültünün oldukça kuvvetlendiği ve bu nedenle modelde ortada verilen yapının etkisinin tümüyle kaybolduğu görülmektedir. Benzer durum $1 \mathrm{~m}$ alıcı aralığı için hesaplanan analitik sinyal sonucunda da (Șekil 5g) görülebilir. 1.5m alıcı aralığı için hesaplanan analitik sinyal diğer- lerine göre gürültü seviyesi azaldığı için ortada verilen yapının etkisini belirgin hale getirmiștir.

Yöntemde farklı alıcı aralıkları seçiminin arazi verileri üzerinde etkisini gösterebilmek için Erzurum ili Tasmasor Nekropolisinde $30 \times 20 \mathrm{~m}^{\prime}$ lik bir alanda toplanan veriler kullanılmıștır. Arazi 
a)

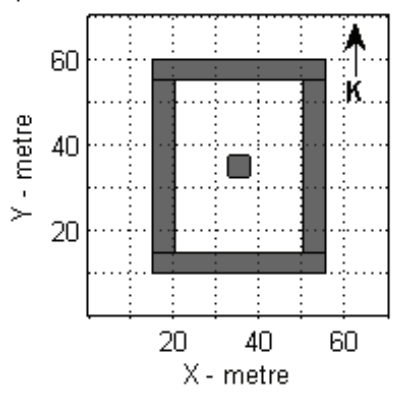

b)

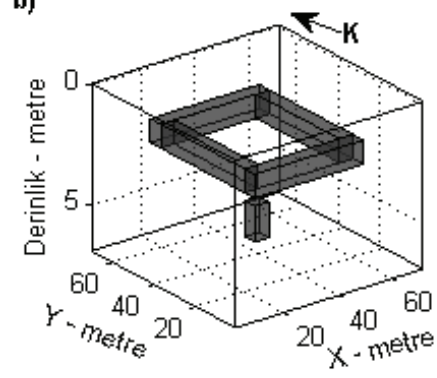

c)

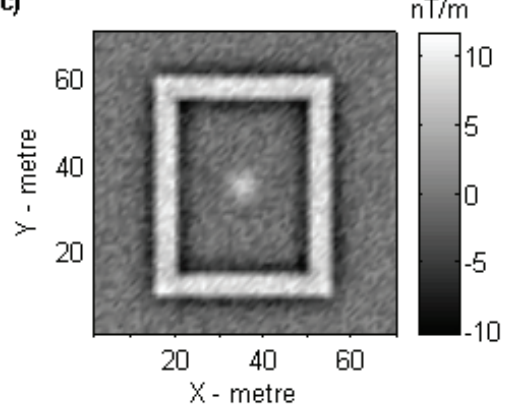

f)

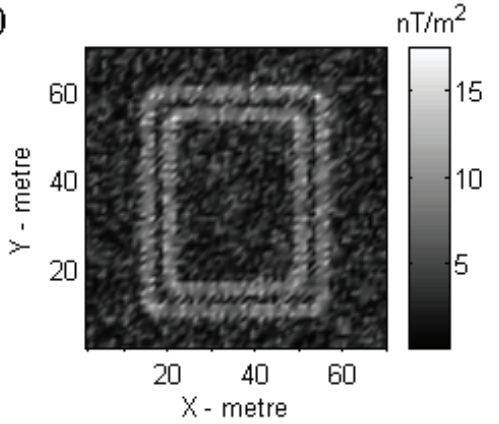

d)

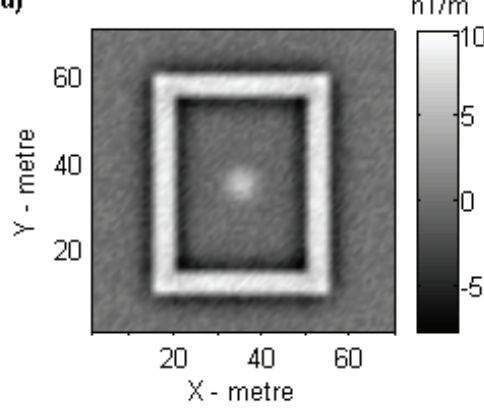

g)

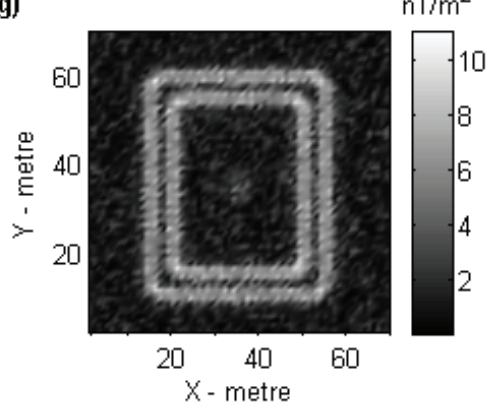

e)

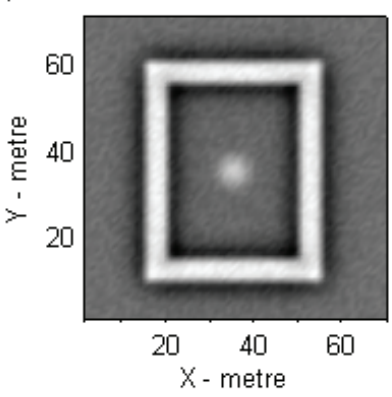

$\mathrm{nT} / \mathrm{m}$

h)

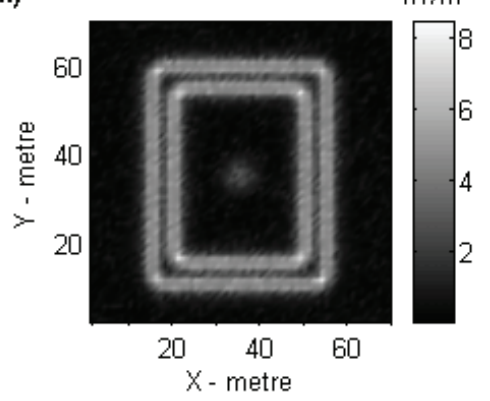

Șekil 5. Beș adet prizmatik yapı kullanılarak olușturulan üç boyutlu yeraltı modeli, farklı alıcı aralıkları için hesaplanan düșey manyetik gradyent görüntü haritaları ve analitik sinyal görüntü haritaları (a) Modelin plan görüntüsü, (b) Modelinin üç boyutlu perspektif görüntüsü, (c) $0.5 \mathrm{~m}$ alıcı aralığı için hesaplanan düșey manyetik gradyent görüntü haritası, (d) $1 \mathrm{~m}$ alıcı aralığı için hesaplanan düșey manyetik gradyent görüntü haritası, (e) $1.5 \mathrm{~m}$ alıcı aralığı için hesaplanan düșey manyetik gradyent görüntü haritası, (f) $0.5 \mathrm{~m}$ alıcı aralığı için analitik sinyal görüntü haritası, (g) $1 \mathrm{~m}$ alıcı aralığı için analitik sinyal görüntü haritası, (h) $1.5 \mathrm{~m}$ alıcı aralığı için analitik sinyal görüntü haritası.

Figure 5. 3D subsurface model that created using five prismatic bodies, calculated vertical magnetic gradient image maps from different receiver separations and analytic signal image maps (a) Plan view of the model, (b) 3D perspective view of the model, (c) The image map of the computed vertical magnetic gradient for $0.5 \mathrm{~m}$ receiver separation, (d) The image map of the computed vertical magnetic gradient for $1 \mathrm{~m}$ receiver separation, (e) The image map of the computed vertical magnetic gradient for $1.5 \mathrm{~m}$ receiver separation, (f) The image map of analytic signal for $0.5 \mathrm{~m}$ receiver separation, (g) The image map of analytic signal for $1 \mathrm{~m}$ receiver separation, (h) The image map of analytic signal for $1.5 \mathrm{~m}$ receiver separation.

verileri toplanırken profil aralığı $0.5 \mathrm{~m}$, ölçü noktası aralığı $0.1 \mathrm{~m}$, alt alıcının yerden yüksekliği ise yaklașık $0.2 \mathrm{~m}$ olarak seçilmiștir. Bu alan üzerinde toplanan düșey manyetik gradyent verilerine ait görüntü haritaları $0.5,1$ ve $1.5 \mathrm{~m}$ alıcı aralıkları için sırasıyla Șekil 6a, Șekil 6b ve Șekil6c'de gös- terilmiștir. Șekil 6a-b-c'de görülen kuzey-doğu güney-batı yönelimli belirti, kazı sonrasında bulunan oldukça düzgün planlı bir mimari komplekse ait taș temel kalıntılarını temsil etmektedir. Tüm alıcı aralıkları için verilen görüntü haritalarında bu belirti düșük genlikle temsil edilmiștir. 
a)

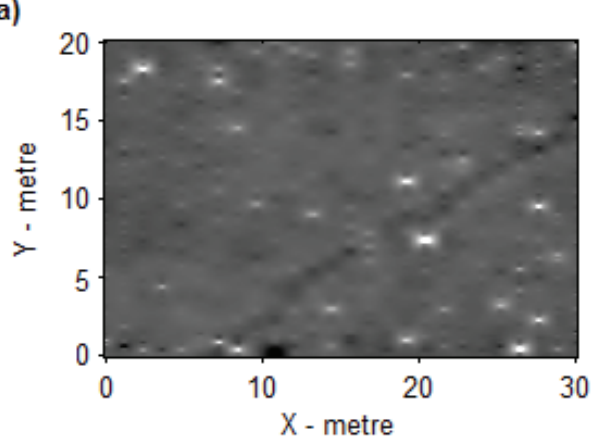

b)

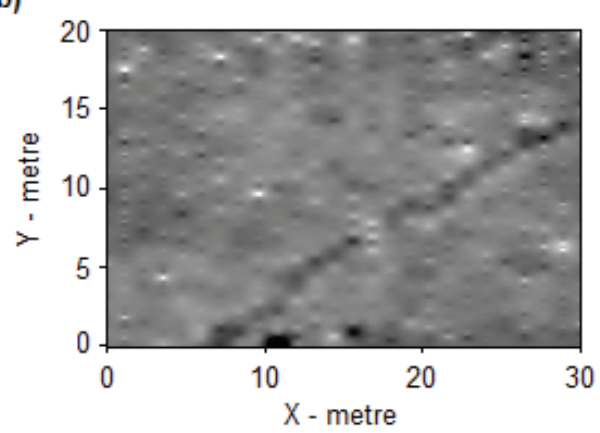

c)

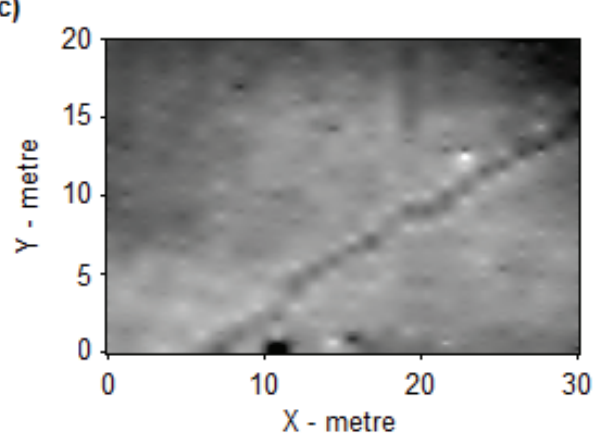

$n T / m$

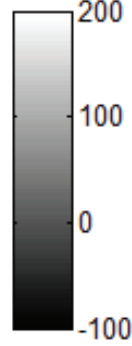

$\mathrm{nT} / \mathrm{m}$

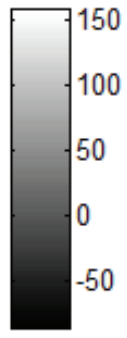

30

$\mathrm{nT} / \mathrm{m}$

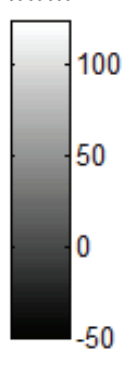

d)

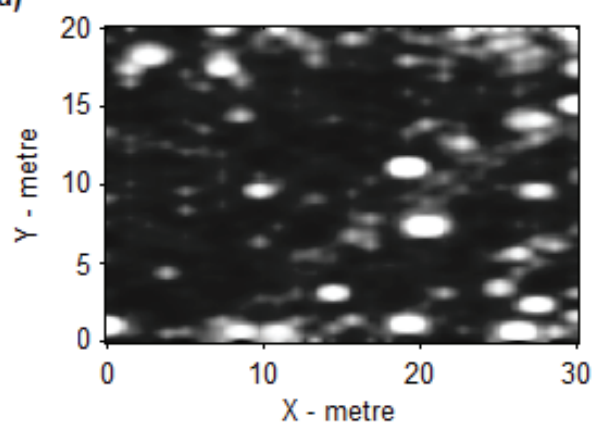

e)

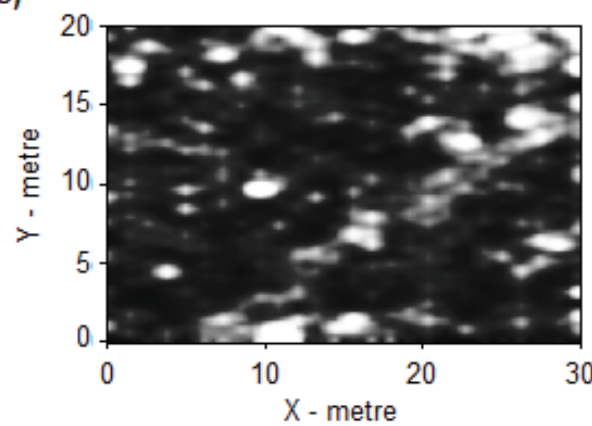

$\mathrm{nT} / \mathrm{m}^{2}$

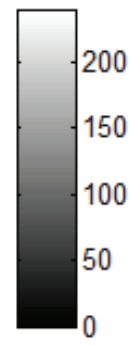

f)

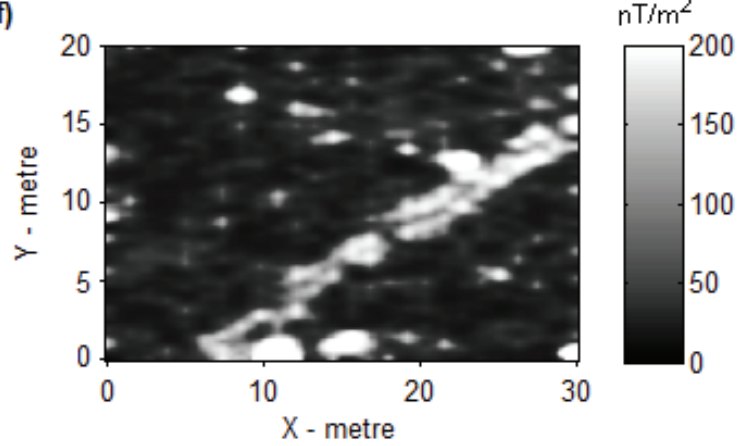

Șekil 6. Erzurum ili Tasmasor Nekropolisi' nde farklı alıcı aralıkları için ölçülen düșey manyetik gradyent verileri görüntü haritaları ve analitik sinyal görüntü haritaları (a) $0.5 \mathrm{~m}$ alıcı aralığı için ölçülen düșey manyetik gradyent görüntü haritası, (b) $1 \mathrm{~m}$ alıcı aralığı için ölçülen düșey manyetik gradyent görüntü haritası, (c) $1.5 \mathrm{~m}$ alıcı aralığı için ölçülen düșey manyetik gradyent görüntü haritası, (d) $0.5 \mathrm{~m}$ alıcı aralığı için analitik sinyal görüntü haritası, (e) $1 \mathrm{~m}$ alıcı aralığı için analitik sinyal görüntü haritası, (f) $1.5 \mathrm{~m}$ alıcı aralığı için analitik sinyal görüntü haritası.

Figure 6. The measured vertical magnetic gradient data image maps and analytic signal image maps from Erzurum province Tasmasor Necropolis (a) The image map of the measured vertical magnetic gradient for $0.5 \mathrm{~m}$ receiver separation, (b) The image map of the measured vertical magnetic gradient for $1 \mathrm{~m}$ receiver separation, (c) The image map of the measured vertical magnetic gradient for $1.5 \mathrm{~m}$ receiver separation, (d) The image map of analytic signal for $0.5 \mathrm{~m}$ receiver separation, (e) The image map of analytic signal for $1 \mathrm{~m}$ receiver separation, (f) The image map of analytic signal for $1.5 \mathrm{~m}$ receiver separation.

Șekil $6 a$ ve Șekil $6 b$ 'de yüksek genlikle temsil edilen küçük boyutlu belirtiler çoğunlukla demir bileșenli nesnelerden (arkeolojik anlam tașımayan) kaynaklanmıștır. Arazi ölçümlerinden önce yüzeyde görülen bu nesneler toplanmıș olsa da, kazı sırasında yüzeye yakın bölgelerden çok sayıda demir nesne çıkartılmıștır. Alıcı aralığının
$1.5 \mathrm{~m}$ olarak seçildiği durumda (Șekil $6 \mathrm{c}$ ) bu nesnelere ait etkiler veriden genel olarak uzaklașmıș ve temel kalıntısına ait belirti daha belirgin bir görüntü almıștır. Șekil 6a-b-c'de farklı alıcı aralıkları için verilen düșey manyetik gradyent verilerinin analitik sinyal görüntü haritaları $0.5 \mathrm{~m}$ alıcı aralığı için Șekil 6d'de, $1 \mathrm{~m}$ alıcı aralığı için Șekil 
$6 e$ 'de ve $1.5 \mathrm{~m}$ alıcı aralığı için Șekil $6 f$ 'de verilmiștir. $0.5 \mathrm{~m}$ alıcı aralığı için hesaplanan analitik sinyal genlikleri (Șekil 6d) daha çok istenmeyen nesnelere ait belirtilerden etkilendiği için temel kalıntısının kenar etkileri bu alıcı aralığı için belirlenememiștir. Șekil 6e'de $1 \mathrm{~m}$ alıcı aralığı için verilen analitik sinyal genlikleri ise benzer șekilde istenmeyen nesnelere ait belirtilerden etkilenmiștir. $1.5 \mathrm{~m}$ alıcı aralığı için hesaplanan analitik sinyal (Șekil 6f) ise diğer sonuçlara göre temel kalıntısının kenarlarını belirlemede daha bașarılı sonuç üretmiștir.

\section{TARTIȘMA VE ÖNERILER}

Yakın yüzey araștırmalarında düșey gradyometre yöntemi günümüzde en sık kullanılan jeofizik yöntemler içerisinde yer almaktadır. Yöntem, alıcıların orta noktasında yer manyetik alanının toplam bileșeninin düșey türevinin ölçülmesi prensibine dayanmaktadır. Her hangi bir fiziksel niceliğin türevinin ölçüldüğü diğer yöntemlerde olduğu gibi düșey gradyometre yöntemi de doğası gereği veride gürültü bileșenlerinin etkisini kuvvetlendiren bir yöntemdir. Bahsi geçen bu durum yöntemin en önemli zayıf noktasıdır. Arazi çalıșmalarında kullanım kolaylığı nedeniyle $0.5 \mathrm{~m}$ alıcı aralığı seçimi artık geleneksel bir hal almıștır. Bu çalıșma kapsamında, farklı alıcı aralıkları seçiminin gürültü varlığını azaltmadaki etkisi araștırılmıștır. Model verileri üzerinde yapılan çalıșmalar neticesinde, ortamda çevresel etkilerin veriye gürültü olarak katılmadığı durumlarda $0.5 \mathrm{~m}$ alıcı aralığının diğer alıcı aralıklarına göre daha duyarlı sonuçlar ürettiği görülmektedir. Ancak gerek yöntemde türev ölçülmesi gerekse çevresel etkilerin veriye ciddi oranda katılması durumunda daha yüksek alıcı aralıkları kullanımının daha uygun olacağı sonuçlardan görülmektedir. Bu nedenle yöntemde alıcı aralıklarının seçimi, arazide yapılacak olan deneme ölçülerinden sonra belirlenmelidir. Bununla birlikte çalıșma kapsamında, analitik sinyal süzgecinin düșey gradyometre yönteminde farklı alıcı aralıkları için nasıl sonuçlar üreteceği konusu da araștırımıștır. Analitik sinyal, ölçülen türev verisinin tekrar türevinin hesaplanmasını gerektirdiğinden dolayı veriye gürültü bileșeninin katıması durumunda düșük alıcı aralıkları için bașarısız sonuçlar üretmiștir.

\section{KATKI BELIRTME}

Yazarlar yapıcı katkılarından dolayı Prof. Dr. Ahmet Tuğrul BAȘOKUR'a (Ankara Üniversitesi Mühendislik Fakültesi Jeofizik Mühendisliği Bölümü) ve Doç. Dr. Bülent ORUÇ’a (Kocaeli Üniversitesi Mühendislik Fakültesi Jeofizik Mühendisliği Bölümü) teșekkür ederler.

\section{KAYNAKLAR}

Affleck, J., 1958. Interrelationships between magnetic anomaly components. Geophysics, 23, 738-748.

Aitken, M.J., 1961. Physics and archaeology. Interscience Publishers Ltd., London.

Arısoy, M.Ö., and Ulugergerli, E.U., 2005. Evaluation of different receiver orientations and receiver separations in magnetic gradiometer method. Journal of the Balkan Geophysical Society, Vol. 8, Suppl. 1, 229-232.

Arısoy, M.Ö., 2007. Düșey ve yatay manyetik gradient verilerinin 3-Boyutlu modellenmesi ve ters çözümü. Yüksek Lisans Tezi, Cumhuriyet Üniversitesi Fen Bilimleri Enstitüsü, Sivas, (yayımlanmamıș).

Barongo, J.O., 1985. Method for depth estimation and aeromagnetic vertical gradient anomalies. Geophysics, 50, 963-968.

Bartington G., and Chapman, C.E., 2004. A high stability fluxgate gradiometer for shallow geophysical survey applications. Archaeological Prospecting, 11, 11-34.

Breiner, S., 1999. Applications Manual for Portable Magnetometers. Geometrics, California.

Haalck, H., 1925. Der erdinduktor als lokalvariometer und seine praktische wervendungsmöglich-keit, Physik, Zeitschrift für techn., 6, 377-380.

Henderson, R.G., and Zietz, I., 1949. The computation of second vertical derivatives of geomagnetic fields. Geophysics, 14, 508-516.

Hood, P., and McClure, D.J., 1965. Gradient measurements in ground magnetic prospecting. Geophysics, 30, 403-410. 
Keating, P., and Pilkington, M., 1990. An automated method for the interpretation of magnetic vertical gradient anomalies. Geophysics, 55, 336-343.

Li, X., 2006. Understanding 3D analytic signal amplitude. Geophysics, 71(2), B13-B16.

Nabighian, M.N., 1972. The analytic signal of two-dimensional magnetic bodies with polygonal cross-section: its properties and used for automated anomaly interpretation. Geophysics, 37, 507-517.

Rikitake, T., and Tanaoka, I., 1960. A differential Proton Magnetometer. Bulletin of the Earthquake Research Institute, 38, 317-328.

Roman, I., and Sermon, T.C., 1934. A magnetic gradiometer, Trans AIME, 110, 373-390.

Tabbagh, A., Desvignes G., and Dabas M., 1997. Processing of $Z$ gradiometer magnetic data using linear transforms and analytical signal. Archaeological Prospecting, 4, 1-13. 
